\title{
THE EUROPEAN LANDSCAPE CONVENTION \\ OF THE COUNCIL OF EUROPE AND THE LANDSCAPE AWARD OF THE COUNCIL OF EUROPE
}

SZERZÖ / BY:

In tribute to Mihály Mőcsényi, With all my heart.

Adopted by the Committee of Ministers of the Council of Europe in Strasbourg on 19 July 200o, European Landscape Convention of the Council of Europe (ETS No. 176) was opened for signature by European States in Florence on 20 October 200o. To date, 39 Council of Europe member States have ratfied the Convention: Andorra, Armenia, Azerbaijan, Belgium, Bosnia and Herzegovina, Bulgaria, Croatia, Cyprus, Czech Republic, Denmark, Estonia, Fi and, France, Georgia, Greece, Hungary, Ireland, Italy, Latvia, Lithuania, Luxembourg, Moldova, Montenegro, North Macedonia, Netherlands, Norway, Poland, Portugal, Romania, San Marino Serbia, Slovakia, Slovenia, Spain, Sweden, Switzerland, Turkey, Ukraine and the United Kingdom. Two States have also signed it: Iceland and Malta. As the first international trea devoted exclusively to all dimensions the landscape the Convention addess

HITPS://D/DI.ORG/

the Organisation's major challenges in the field of human rights, democracy and the rule of law with a view to sustainable development Its signatory States have declared themselves "concerned to achieve sustainable developnt to achie us rased a balanced and harnonexs re considering the cultura dinver considering the cultural dimension of (The concept of sustain 作 integrating the environmental, cultur social and economic dimensions, by

pplying them to the entire territory. The landscape is the result of many change-producing actions resulting from the activity of various stakeholders in territorial processes in highly varled ways and on differing scales of time and space. Such activities may be the outcome of action by public authorities in establishing a large-scale infrastructure or of individual action in a rest space. The legal recognition of landcape implies rights and responibilties on the part of all institutions and cit- izens towards their living environment. Although each citizen must contribute to preserving the quality of the landscape it is the authorities that are responsible for establishing the general framework for The Convention accordingly lass down The Convention accordingly lays down guide the adoption of net that mo scape policies and the estional landinternational co-op thernational co-operation in this area. The Convention provides that existing competent Committees of Experts of the Council of Europe, set up under its Statute, are designated by the Committee of Ministers of the Organisation, to monitor its implementation. The Work Programme of the Convention, adopted by the Council of Europe Conferences on the Convention and the Steering Committee for Culture, Heritage and Landscape (CDCPP), is implemented by the Secretariat General of the Council of Europe which transmits reports on the work carried out, and on the operation carried out, tion to the Committee of Ministers.

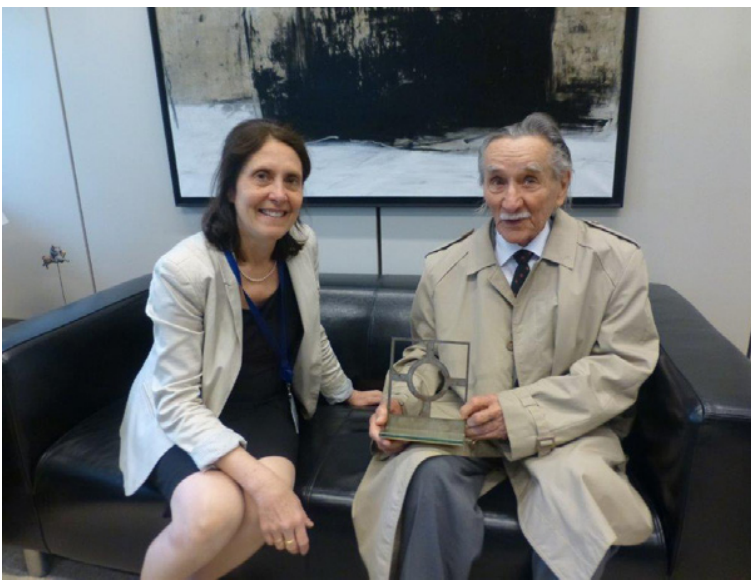
development, flandscape in the lives of he place beings and societies, has been carProgramme of the Convention. Since the adoptin of the Europ Landscape Convention, major progres has been made towards the establishment of landscape policies at nation regional and local level. Drawing on shared objectives, these policies foste the quality of a common living environment. The notion of landscape has bee progressively introduced into the political agenda of governments and landscape actors: an important international network of cooperation for the mplementation of the Convention has developed: the concept of landscape as defined the Convention is increasingly recognised by the public authorities an by the population; new forms of co-opeation are emerging between different levels of authority - national, regiont levels of authority - national, regional depits of landscape in the lives of human Since the adoption of the European cific laws and regulations referring to dscape are adopted and institutional structures are put in place; States r regions co-operate across borders for transfrontier landscapes; landscape prizes referring to the Council of Europe pizes refering to the Council or Europe ity pros sy programmes refenting to the Conver lon referring to the principles of the Convention are being set up, and people fee ore and more concerned and active. The landscape represents a mosaic of the four dimensions of sustainable deveopment: natural, cultural, social and economic. Governments committed to implementing the principles of good go ernance must take into consideration the invaluable value of the landscape for the human being, and include the andscape dimension in their national, regional and local policies. It is also up to everyone to respect the lis also up ubstance for present and future gento take care of it both in landscape an erations. The opening of the European Landscape Convention to non-European States will be an opportunity to reaffirm the universality of the landscape dimension of human rights and democracy. It 作 of Europe to the implementation of the United Nations 2030 Agenda for Sustainable Development. This represents a contribution by the Council of Europe to the implementation of the United Nations 2030 Agenda for Sustainable Development, in particular with regard to Goals 3 (Good health and well-being), 11 (Sustainable cities and communities) and 15 (Life on land), in particular. 